ks. Stanisław Ormanty TChr.

\title{
Człowiek jako istota osobowa w świetle antropologii biblijnej
}

W ramach biblijnego spojrzenia na człowieka jako na istotę religijną decydującą rolę odgrywają dwa podstawowe wymiary człowieka: wymiar osobowy i społeczny. Istota osobowa i istota społeczna pozostają w ścisłym związku. Do ludzkiego bycia osobą przynależy ukierunkowanie na wspólnotę i rozwój we wspólnocie; specyficzna ludzka wspólnota realizuje się dzięki szacunkowi i wspieraniu osobowości człowieka. Osoba ludzka jest relacją; dopiero w relacji człowiek staje się w pełni osobą. Mówiąc inaczej; osoba ludzka istnieje w komunikacji; osiagga spełnienie w komunikacji ${ }^{1}$.

W niniejszym artykule zasygnalizowany zostanie szkic orientacyjny osobowego wymiaru człowieka na tle antropologii biblijnej, która jest - jak to zostanie w niniejszym pokazane - bazą dla antropologii filozoficznej.

\section{Człowiek jako istota osobowa}

W Biblii Starego Testamentu Bóg jest Osobą (Wj 33, 14). Hebrajski zwrot: (pānaj) znaczy: postać, oblicze ${ }^{2}$, które ujawnia całą jednostkę ludzką (Kpł 19, $\left.32-p^{e} n \hat{e}\right)$ lub Boga ${ }^{3}$. Do wielkiego wzbogacenia nazwy „persona" przyczyniły się dwie prawdy religii chrześcijańskiej: o Trójcy Świętej i o Wcieleniu.

Autorzy biblijni nie podejmują wyraźnego rozróżnienia między słowem a osobą, która je wypowiada. Słowo jest pewnego rodzaju „manifestacją” osoby, która je artykułuje; dana osoba jest obecna w swoich słowach ${ }^{4}$.

${ }^{1}$ Zob. M. Filipiak, Aksjologiczne treści antropologii biblijnej, Lublin 1991, s. 79101; A. GrzegorczyK, Etyka $w$ doświadczeniu wewnętrznym, Warszawa 1989, s. 118-146; K. L. Schmitz, Geografia osoby ludzkiej, [w:] Kosmos i człowiek, Poznań-Warszawa 1989, s. 135-155 (Kolekcja Communio, 4).

${ }^{2}$ Zob. S. ŁACH, Księga Wyjścia. Wstęp - przekład z oryginału - komentarz, Poznań 1964, s. 280.

${ }^{3}$ Zob. F. Zorell, E. Vogt, $p^{e}$ ê, [w:] Lexikon hebraicum et aramaicum, t. 5, Roma 1974, s. 654n; W. Granat, Personalizm chrześcijański. Teologia osoby ludzkiej, Poznań 1985, s. 55; A. Rodziński, Osoba i kultura, Warszawa 1985, s. 21-27. 
Zgodnie z klasyczną definicją Boecjusza († 525): osoba jest poszczególną substancją natury rozumnej (naturae rationalibis individua substantia) ${ }^{5}$. Cechą osoby jest zatem niepodzielna samodzielność, która ugruntowana jest w naturze rozumnej. Charakterystyczną niepowtarzalność osoby można opisać przez wyróżnienie różnych treści: osoba to indywiduum ugruntowane w naturze duchowej, posiadające samodzielność niezastąpioną bądź niewymienialną. Osoba jako indywiduum kształtowane przez ducha jest niepowtarzalną i samodzielną jednością i całością. Mówiąc krótko: osoba jest indywidualnością duchową w swym jednorazowym byciu sobą ${ }^{6}$.

W spojrzeniu biblijnym należy wyróżnić dwa zasadnicze momenty: w holistycznym myśleniu biblijnym człowieka osoba jest całością ciała, duszy i ducha; podkreślając szczególne miejsce człowieka, Biblia jako element konstytuujący osobę wyróżnia duchowośćc .

\section{Człowiek jako całość ciała, duszy i ducha}

W Starym Testamencie spotykamy różne „organy”, które są podkreślonymi przejawami tej całości, jaką według myśli biblijnej stanowi człowiek. Każdy z tych „organów” ma to do siebie, że to w nim właśnie może ujawniać się cała osobowość człowieka; bowiem każdy z nich może być podmiotem myśli i uczuć. Biblia Starego Testamentu nie postrzega ich jako pewne określone części człowieka, ale są to funkcjonalne przejawy osobowego życia człowieka. To całościowe postrzeganie przejawów życia człowieka jest specyfiką hebrajskiego sposobu myślenia8 ${ }^{8}$.

Zgodnie z rozumieniem biblijnym człowiek jest żywą jednością ciała (bāsáarr), duszy (nefeš) i ducha (rûach ${ }^{9}$, jednością somatyczno-psychicznopneumatyczną. Ciało, dusza i duch są podstawowymi fenomenami istoty ludzkiej, są istotowymi strukturami (rzeczywistość statyczna) bądź istotowymi funkcjami (dynamiczne siły działania), które tworzą jednolitą całość przenikniętą duchem ${ }^{10}$. Wiele tekstów biblijnych mówi także skrótowo o całości cielesno-duchowej, łącząc w ten sposób ze sobą duszę i ducha w jedną duchową duszę, gdyż dusza (zasada wszelkiego życia) wydaje się być u człowieka w całości przeniknięta duchem ${ }^{11}$.

${ }^{4}$ Zob. M. FILIPIAK, Aksjologiczne treści antropologii biblijnej, dz. cyt., s. 9.

${ }^{5}$ Cyt. za: M. Gogacz, Wokót problemu osoby, Warszawa 1974, s. 36, przyp. 13.

${ }^{6}$ Zob. W. Granat, Osoba ludzka, Sandomierz 1961, s. 244-254; TEnże, Personalizm chrześcijański. Teologia osoby ludzkiej, dz. cyt., s. 62-72; A. RoDziński, Osoba i kultura, dz. cyt., s. 44-57.

${ }^{7}$ Zob. M. FilipiaK, Biblia o człowieku, Lublin 1979, s. 79n.

${ }^{8}$ Zob. tamże, s. 33; K. H. SchelkLe, Teologia Nowego Testamentu, t. 1, Kraków 1984, s. 101-104.

${ }^{9}$ Zob. A. Gelin, Pismo święte o człowieku, Paris 1971, s. 14n.

${ }^{10}$ Zob. L. Wciórka, Filozofia człowieka, Warszawa 1982, s. 109-121. 


\section{FENOMENY PODSTAWOWE: CIAŁO, DUSZA, DUCH}

Ciało i duchowa dusza uznane są za podstawowe fenomeny człowieka, gdy w jahwistycznym opisie stworzenia w Starym Testamencie powiedziane jest: „Wtedy to Pan Bóg ulepił człowieka z prochu ziemi i tchnął w jego nozdrza tchnienie życia" (Rdz 2, 7).

W tym przedstawieniu, w którym Bóg opisany jest na sposób antropomorficzny, obrazy ziemi i tchnienia wyrażają głęboki sens: człowiek składa się z - pochodzącego z prochu ziemi - materialnego ciała oraz z duchowej duszy, pomyślanej tutaj jako tchnienie. Myślenie hebrajskie zwykle porusza się w tej dwojakości ${ }^{12}$.

W 1 Tes 5, 23 znaleźć można odosobniony nowotestamentalny fragment, w którym duch i dusza nazwane zostają osobno: „Sam Bóg niech was całkowicie uświęca, aby nienaruszony duch ( $\pi \nu \in \hat{u} \mu \alpha)$ wasz, dusza ( $\left.\psi \nu \chi \eta)^{\prime}\right)$ i ciało $(\sigma \omega \hat{\omega} \mu \alpha)$ bez zarzutu zachowały się na przyjście Pana naszego, Jezusa Chrystusa”.

W tym miejscu całość człowieka ujawnia się w wyrazisty sposób pod postacią tych trzech podstawowych fenomenów: ducha ${ }^{13}$, duszy ${ }^{14}$ i ciała $^{15}$.

Trzy podstawowe fenomeny: ciało, dusza, duch opisywane są w Starym i Nowym Testamencie przy pomocy nie tych samych, lecz zmieniających się pojęć. Większą trudność w rozumieniu niesie ze sobą Pawłowa para pojęć: ciała $(\sigma \alpha ́ \rho \xi)^{16}$ i ducha $(\pi \nu \in \hat{v} \mu \alpha)$, która często rozumiana jest jako przeciwieństwo ciała i ducha ${ }^{17}$.

Święty Paweł ma tu jednak każdorazowo na myśli całego człowieka, to znaczy podstawowe postawy całego człowieka, a mianowicie człowieka poddanego władzy własnego ,ja” oraz człowieka ukierunkowanego na Boga ${ }^{18}$.

\section{JEDNOŚĆ: BIEGUNOWA, KOMPLEMENTARNA, ORGANICZNA}

Nasuwa się pytanie: jaki model ukazujący jedność pozwoli nam scharakteryzować prawdziwe biblijne rozumienie relacji ciała, duszy i ducha?

Aby móc wyraźniej ukazać specyfikę modelu biblijnego, należy najpierw naszkicować poglądy dotyczące problemu duszy i ciała w antropologii greckiej.

${ }^{11}$ Zob. L. Stachowiak, Biblijna koncepcja człowieka, [w:] W nurcie zagadnień posoborowych, red. B. BEJzE, t. 2, Warszawa 1968, s. 209-225.

${ }^{12}$ Zob. J. Lemański, Pięcioksiąg dzisiaj, s. 163-165 (Studia Biblica, t. 4).

${ }^{13}$ Zob. E. Schweizer, $\pi \nu \in \hat{u} \mu \alpha$, [w:] TWNT, t. 6, s. 413-444.

${ }^{14}$ Zob. E. Schweizer, $\psi v \chi \eta$, [w:] TWNT, t. 9, s. 647-650.

${ }^{15}$ Zob. E. Schweizer, $\sigma \omega \hat{\mu} \mu \alpha$, [w:] TWNT, t. 7, s. 1054-1064.

${ }^{16}$ Zob. E. Schweizer, $\sigma \alpha ́ \rho \xi$, [w:] TWNT, t. 7, s. 124-138.

${ }^{17}$ Zob. K. Romaniuk, Soteriologia św. Pawła, Warszawa 1983, s. 172-174.

${ }^{18}$ Zob. J. StęPIEŃ, Teologia świętego Pawła, Warszawa 1979, s. 27-36. 
U Platona mamy do czynienia z silnym dualizmem ciała i duszy ${ }^{19}$. Zgodnie zjego ujęciem, ciało i dusza są przeciwieństwami, które prowadzą w człowieku przymusowa koegzystencję. Preegzystująca dusza w wyniku kary zostaje zmuszona do zamieszkania w ciele, które staje się jej więzieniem; dusza czeka na wyzwolenie z więzienia ciała. Dzięki przeniknięciu duchem dusza jest czymś bardzo wartościowym, podczas gdy ciało z powodu swojej materialności jest czymś poślednim ${ }^{20}$. Owo dualistyczne wartościowanie ciała i duszy przejął w swojej antropologii św. Augustyn ${ }^{21}$. Za sprawą historii oddziaływania jego myśli w teologii chrześcijańskiej św. Augustyn przyczynił się do pewnego zniekształcenia biblijnego poglądu na człowieka.

Arystoteles łączy ze sobą ciało i duszę. W jego „hilemorfizmie” (wszelki byt składa się z materii i formy), w odniesieniu do relacji ciało-dusza stwierdza się, że dusza jest formą ciała. W ten sposób góruje nad ciałem jako siła kształtująca ${ }^{22}$.

Podejście arystotelesowskie przyjmuje św. Tomasz. Na sposób ściśle monistyczny uznaje duszę za jedyną formę ciała ${ }^{23}$. Takie podejście staje się panujące w teologii scholastycznej i aż po czasy neoscholastyki stanowi dominujący model wyjaśniający.

Kontynuując kierunek platonizmu, hellenistyczne myślenie charakteryzuje się dychotomizmem lub trychotomizmem ${ }^{24}$. W dychotomizmie, w dwudzielności, obok siebie stoją ciało i dusza jako dwie nieruchome części; w trychotomizmie, w trójdzielności, ciało, dusza i duch znajdują się obok siebie. Cechą charakterystyczną tego modelu jest to, że ciało, dusza i duch nie są ze sobą wewnętrznie połączone i dlatego zostają rozłączone po śmierci.

Prawie we wszystkich księgach Starego Testamentu ukazany jest człowiek jako nierozdzielna całość psychofizyczna. Należy więc wykluczyć z antropologii biblijnej trychotomię ${ }^{25}$.

${ }^{19}$ Zob. W. Tatarkiewicz, Historia filozofii, t. 1, Warszawa 1983, s. 89-91; E. Gilson, Elementy filozofii chrześcijańskiej, Warszawa 1965, s. 189.

${ }^{20}$ Zob. B. A. G. FulLer, Historia filozofii, t. 1, Warszawa 1963, s. 165.

${ }^{21}$ Zob. E. Gilson, Elementy filozofii chrześcijańskiej, dz. cyt., s. 190; M. Krąpiec, Z. Zdybicka, Augustyn, [w:] Encyklopedia katolicka, t. 1, Lublin 1973, k. 1095-1099.

${ }^{22}$ Zob. W. Tatarkiewicz, Historia filozofii, t. 1, dz. cyt., s. 11-12; E. Gilson, Elementy filozofii chrześcijańskiej, dz. cyt., s. 190; M. KRĄPIEC, Arystoteles, [w:] Encyklopedia katolicka, t. 1, dz. cyt., k. 963-967.

${ }^{23}$ Zob. W. TAtarkiewicz, Historia filozofii, t. 1, dz. cyt., s. 278; E. Gilson, Elementy filozofii chrześcijańskiej, dz. cyt., s. 191n.

${ }^{24}$ Zob. L. Stachowiak, Zagadnienie dualizmu antropologicznego w Starym Testamencie i literaturze międzytestamentalnej, STV 7 (1969) nr 2, s. 9n; TENŻE, Biblijna koncepcja człowieka, [w:] Wnurcie zagadnień posoborowych, red. B. BEJZE, dz. cyt., s. 221.

${ }^{25}$ Zob. M. FiliPIAK, Biblia o człowieku, dz. cyt., s. 65-66. 
W myśleniu biblijnym ciało, dusza i duch tworzą holistyczną, przenikająca się wzajemnie całość. Bliżej oznacza to, iż ciało, dusza i duch człowieka to biegunowa, komplementarna i organiczna jedność. Jedność biegunowa - na kształt biegunów magnetycznych bądź elektrycznych - oznacza to, że mamy tu do czynienia z różnorodnością fenomenów, ale nie z ich oddzieleniem; jest to napięcie, a nie walka; jest to zależność, ale nie wchłonięcie. Wyrażając to pozytywnie: jest to jedność komplementarna. Nie jest to zwykłe bycie obok siebie, lecz bycie ze sobą; nie jest to wzajemne redukowanie siebie, lecz wzajemne uzupełnianie się ${ }^{26}$.

Jako żywe uzupełnianie się jest to także jedność organiczna; nie jest to jakiś luźny zewnętrzny związek, lecz wewnętrzne połączenie. Zatem nie jest to wzajemne izolowanie się, lecz wzajemne przenikanie i oddziaływanie.

To całościowe wzajemne przenikanie się może zostać przedstawione w obrazie geometrycznym koła: osoba jest kołem, w którym trzy wymiary ciało, dusza, duch działają wspólnie jak trzy przecinające się okręgi.

\section{Człowiek jako duchowość}

To, co czyni człowieka stworzeniem niepowtarzalnym pomiędzy wszystkimi innymi stworzeniami ziemskimi, jest duch. Tylko i wyłącznie przy stworzeniu człowieka - jak w głęboki sposób przedstawia to opis jahwistyczny stworzenia - Bóg wykonuje szczególną czynność: tchnienie życia $(\mathrm{Rdz} 2,7)^{27}$.

Przy pomocy tego symbolu ukazane zostaje udzielenie czegoś boskiego, duchowej duszy. To dopiero duch konstytuuje osobę, tzn. tam, gdzie jest duch, można mówić o osobie ${ }^{28}$.

\section{Rozum I WOLNOŚć}

Duch zgodnie z perspektywą biblijną dzieli się z kolei na dwie podstawowe siły rozumu i wolności lub też ujmując rzecz ściślejej, na dwie podstawowe siły rozsądku i woli ${ }^{30}$. Te podstawowe siły powodują następujące działania: poznanie i decyzję, zrozumienie i wolne działanie, myślenie i poszanowanie odpowiedzialności, wiedzę i sumienie. Człowiek jest zatem istotą posiadającą rozum i wolność ze wszystkimi wynikającymi z tego działaniami.

${ }^{26}$ Zob. A. Rodziński, Osoba i kultura, dz. cyt., s. 51-57.

${ }^{27}$ Zob. J. Lemański, Pięcioksiag dzisiaj, dz. cyt., s. 163-165.

${ }^{28}$ Zob. K. Косн, Der Güter Gefährlichstes, die Sprache, dem Menschen gegeben. Überlegungen zu Gen 2, 7, BN 48 (1988), s. 50-60.

${ }^{29}$ Zob. W. Granat, Personalizm chrześcijański. Teologia osoby ludzkiej, dz. cyt., s. 94n.

${ }^{30}$ Zob. J. PASTuszKa, Znaczenie woli w życiu człowieka, [w:] W kierunku człowieka, red. B. BeJze, Warszawa 1971, s. 285-295; A. B. STEPIEN, Wstęp do filozofii, Lublin 1976, s. 185-192. 
W sposób pośredni obydwie osobowe siły i wynikające z nich czynności przedstawione są w opisie upadku człowieka na skutek grzechu ( $R d z 3,1-8)$. W etycznej sytuacji podejmowania decyzji chodzi o to, czy spożywać, czy nie spożywać z „drzewa poznania dobra i zła” - w sposób jak najbardziej wyraźny ujawnia się współdziałanie rozumu i wolności. Można zauważyć, jak działają tutaj rozumowe argumenty węża; widać wolność Ewy, która daje przyzwolenie, jej decyzję, a następnie decyzję Adama, by „zjeść” kuszący owoc ${ }^{31}$; widać następujące potem rozpoznanie, iż postąpili niesłusznie, i wreszcie - w obrazie nagości i ukrywania się przed Bogiem - nieczyste sumienie ${ }^{32}$.

W sposób dobitny i wyczerpujący cała literatura „mądrościowa” zajmuje się rozumem i wolnością człowieka (szczególnie Księga Przysłów, Księga Mądrości, Mądrości Syracha) $)^{33}$. Literatura ta pod zbiorczym pojęciem mądrości sławi rozum człowieka we wszystkich jego rodzajach i nawołuje do prawego działania ${ }^{34}$. Syrach w sposób skrótowy mówi o owym szczególnym darze, jaki Bóg-Stwórca dał ludziom: „Napełnił ich wiedzą i rozumem, o złu i dobru ich pouczył" $(17,7)$.

Zgodnie z myślą Syracha (17, 5-13), Bóg obdarzył człowieka wolną wolą, zdolnością mówienia i postrzegania, zdolnością refleksji, rozumem, wiedzą, zdolnością rozróżniania dobra i zła ${ }^{35}$.

W refleksji systematycznej wyróżnić można następujące stwierdzenie: rozum i wolność konstytuują osobę ludzką. Poprzez rozum człowiek posiada zdolność nie tylko rozpoznawania tego, co inne, ale także postrzegania siebie

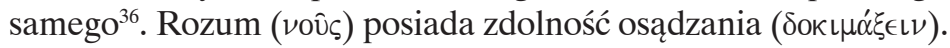

U apostoła Pawła szczególnie wyakcentowana jest zdolność do podejmowania osądów moralnych, rozpoznawania „tego, co przystoi” ( $\tau \dot{\alpha}$ к $\alpha \theta \dot{n} \kappa o \nu \tau \alpha-R z 1$, 28), tego, co doskonałe, miłe, dobre, odpowiadające woli Bożej (Rz 12, 2) ${ }^{37}$.

Człowiek jest zatem istotą posiadającą samoświadomośćc ${ }^{38}$. Dzięki wolności człowiek posiada zdolność nie tylko do wybierania pomiędzy różnymi możliwościami, lecz także kierowania swoimi różnymi motywami. Człowiek jest zatem istotą, która dysponuje sobą, stanowi o sobie.

${ }^{31}$ Zob. W. Chrostowski, Anatomia pokusy (Rdz 3, 1-6), PP 5 (1984), s. 198-207.

32 Zob. J. Sulowski, Czy Adam i Ewa „,byli nadzy”, Łódź 1998, s. 23-34; Z. KIERNIKOwsKi, Dwoje jednym ciałem, Warszawa 2000, s. 44-56.

${ }^{33}$ Zob. S. Ротоскі, Mądrość na Starożytnym Wschodzie i w Izraelu, [w:] Wprowadzenie w myśl $i$ wezwanie ksiąg biblijnych. Mądrość starotestamentowego Izraela, red. S. РотоскI, J. WARZECHA, t. 6, Warszawa 1999, s. 13-31.

${ }^{34}$ Zob. S. Potocki, Rady i mądrości. Jak rozumieć Pismo święte, t. 5, Lublin 1993, s. 6.

${ }^{35}$ Zob. M. FilipiaK, Aksjologiczne treści antropologii biblijnej, dz. cyt., s. 41.

${ }^{36}$ Zob. J. Gnilka, Teologia Nowego Testamentu, Kraków 2002, s. 56-60.

${ }^{37}$ Zob. tamże, s. 57 n.

${ }^{38}$ Zob. A. B. StęPIEŃ, Wstęp do filozofii, Lublin 1976, s. 98n 
Poprzez samoświadomość człowiek posiada relację do siebie samego i samopoznanie. Dzięki możliwości dysponowania sobą człowiek posiada kontrolę nad samym sobą, możliwość decydowania o sobie i potwierdzania siebie. Poznanie siebie i afirmacja siebie są przesłankami dla ludzkiego „ja”, bycia sobą ${ }^{39}$. Posiadanie ,ja” z kolei jest warunkiem dla „ty”, czyli dla ludzkiego spotkania i ludzkiej wspólnoty.

W Starym Testamencie jest bardzo wiele razy zaakcentowana prawda, że człowiek nie może obejść się bez drugiego człowieka na płaszczyźnie materialnej i kulturalnej, a także do pełnego rozwoju w dziedzinie religijnej niezbędny jest drugi człowiek ${ }^{40}$. Stary Testament niejednokrotnie podkreśla solidarność w dobru jak też i w złu; dotyczy to pośredników, którzy stanowią źródło błogosławieństwa Bożego dla danej społeczności (Rdz 12, 2-3), ale także takich pośredników, którzy sprowadzają zło (2 Sm 21, 24).

Z innej perspektywy wyrazić to można następująco: dzięki współdziałaniu rozumu i wolności człowiek staje się istotą etyczną ${ }^{41}$. Dzięki rozumowi człowiek posiada wgląd w różnicę pomiędzy dobrem a złem; dzięki wolności człowiek posiada wybór podjęcia decyzji na rzecz dobra lub zła. W ten sposób człowiek jest osobiście odpowiedzialny za swe działanie; jest istotą odpowiedzialną.

Owo bycie odpowiedzialnym ujawnia się w fenomenie sumienia ${ }^{42}$. Su-

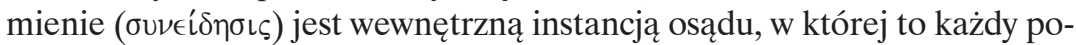
jedynczy człowiek doświadcza, czy jego osobiste działanie jest dobre czy złe. Sumienie jest wewnętrzną instancją decydującą, w której każdy pojedynczy człowiek postanawia pójść drogą działania osobiście dla niego właściwą.

Tę władzę i zdolność osądu moralnego apostoł Paweł przypisuje wszystkim ludziom ${ }^{43}$ (2 Kor 4, 2n): „Poddajemy siebie samych w obliczu Boga osądowi sumienia każdego człowieka" (zob. także Rz 2, 14n; 13, 5).

W sumieniu jest jądro moralnej tożsamości, a przez to najgłębszej tożsamości własnego ,ja” człowieka. W sumieniu ujawnia się ostateczna niemożność rozporządzania ludzka osobą.

\section{JĘZYK I KULTURA}

W ujęciu biblijnym bezpośrednim skutkiem otrzymania ducha, zewnętrznie dostrzegalnymi skutkami działania rozumu i wolności są podarowane człowiekowi dwie niepowtarzalne zdolności: język i kultura ${ }^{44}$.

${ }^{39}$ Zob. L. WCIÓRKA, Filozofia człowieka, dz. cyt., s. 66n.

${ }^{40}$ Zob. M. FilipIAK, Biblia o człowieku, dz. cyt., s. 97.

${ }^{41}$ Zob. H. D. Wendland, Ethik des Neuen Testament, t. 4: Grundrisse zum Neuen Testament, Göttingen 1978, s. 4-31.

${ }^{42}$ Zob. J. Gnilka, Teologia Nowego Testamentu, dz. cyt., s. 60-63.

${ }^{43}$ Zob. tamże, s. 60. 
Wskazanie na człowieka jako na istotę językową pojawia się w Księdze Rodzaju (2, 19n) - wśród wszystkich stworzeń tylko Adam potrafi mówić i dzięki temu wolno mu nadawać wszystkim zwierzętom nazwy ${ }^{45}$. Zdolność mówienia człowieka umożliwia rozmowę, tzn. wymianę myśli poprzez pytanie i odpowiedź. To, że ta umiejętność człowieka dana mu od zarania była wyróżnieniem, staje się widoczne w rozdziałach 3 i 4 Księgi Rodzaju, w których Bóg prowadzi rozmowy z pierwszymi ludźmi, Adamem i Ewą, a także Kainem ${ }^{46}$.

O człowieku jako o istocie kulturowej mówi Księga Rodzaju $(2,15)$ : Bóg umieszcza człowieka w ogrodzie Eden, aby ten , uprawiał go i doglądał”. Człowiekowi polecone jest zatem kultywowanie i zachowywanie ${ }^{47}$. Z perspektywy tego podwójnego zadania należy także interpretować często cytowane polecenie tworzenia kultury z Księgi Rodzaju $(1,28)$, by czynić sobie ziemię „poddaną"48.

W odniesieniu do człowieka jako do istoty językowej należy poczynić następujące uwagi systematyczne: język jest zmysłowo doświadczalnym wyrazem duchowości człowieka. Duchowe pojęcia myśli stają się słyszalne w dźwiękach wymienianych słów i widzialne w znakach pisma ${ }^{49}$. Dzięki językowi składającemu się ze słów ujawniają się decydujące, specyficzne cechy człowieka: ponieważ język nie jest wrodzonym instynktem, lecz zostaje nabyty poprzez włączenie do grupy językowej, jest on porozumiewaniem się, które opiera się na tradycji. W taki sposób człowiek okazuje się także istotą posiadającą tradycję. Ponieważ język werbalny umożliwia przekazywanie doświadczeń i wiedzy, człowiek może pouczać innych dzięki przekazywaniu informacji. W ten sposób człowiek okazuje się istotą uczącą się i nauczającą. Ponieważ język werbalny jest możliwy tylko dlatego, że człowiek potrafi w pamięci długoterminowej przechowywać nieobecne rzeczy i przeżycia w postaci pojęć, to zdolność zapamiętywania jest czymś decydującym dla człowieka. W taki sposób człowiek okazuje się być istotą pamiętającą.

${ }^{44}$ Zob. A. Rodziński, Osoba i kultura, dz. cyt., s. 120-125; A. B. StepIEŃ, Wstęp do filozofii, Lublin 1976, s. 131-140; P. JARoszYŃski, Filozofia kultury, [w:] Rozumieć człowieka i jego działanie, red. P. GONDEK, t. 2, Lublin 2000, s. 221-242.

${ }^{45}$ Zob. A. M. Besnard, Le mystère du nom, Paris 1962, s. 25-29; J. Synowiec, Poczatki świata i ludzkości według Księgi Rodzaju, Kraków 2001³, s. 111; T. Brzegowy, Pięcioksiag Mojżesza, Tarnów 1997, s. 158-159; J. LemAŃsKi, Pięcioksiag dzisiaj, dz. cyt., s. 169.

${ }^{46}$ Zob. R. Brandscheidt, Kain und Abel. Die Sündenfallerzählung des Jahwisten in Gen 4, 1-16, TThZ 106 (1997), s. 1-21; W. PIKOR, Zbawienie-zmaganie o Boże oblicze na twarzy Kaina (Rdz 4, 1-16), „Verbum vite” 1 (2002), s. 29-39.

${ }^{47}$ Zob. J. Sulowski, The Mission of the Man According to Gen 2, 4b-17, t. 2, Poznań 2001, s. 7-27 (Theologia Bogoslovie, 1.2).

${ }^{48}$ Zob. M. W. H. Schmid, Die Schöpfungsgeschichte, t. II, Neukirchen 1967, s. 142, 147; J. Kudasiewicz, Nowotestamentalne rozumienie pracy na tle ówczesnych pogladów, [w:] Życie spoteczne w Biblii, red. G. WitaszeK, Lublin 1997, s. 45

${ }^{49}$ Zob. J. Życiński, Język i metoda, Kraków 1983, s. 23 n. 
Ponieważ człowiek dzięki językowi może przekazywać swoje osobiste myśli i uczucia, dlatego język umożliwia komunikację międzyludzką. W ten sposób człowiek okazuje się istotą komunikującą się.

Skoro dzięki językowi może prowadzić z innymi ludźmi rozmowę polegającą na mówieniu i odpowiadaniu, dlatego też język umożliwia dialog; człowiek okazuje się istotą dialogiczną. Także dzięki językowi może zwracać się do Boga ${ }^{50}$, dlatego też język umożliwia modlitwę; w ten sposób człowiek okazuje się istotą modlącą się ${ }^{51}$.

W odniesieniu do człowieka jako do istoty kulturowej należy poczynić następujące uwagi systematyczne: kultura jest obiektywizowaną na zewnątrz duchowością człowieka; jest ona, jak zauważył G. W. F. Hegel, obiektywnym duchem ${ }^{52}$. Kultura wyrasta z rozumu i wolności człowieka. Rozum i wolność posiadają, jak i rozwijają na zewnątrz, nieskończoną otwartość. Rozum jest nieskończoną otwartością na poznanie. Poszukuje on poznania w sposób bezgraniczny i ciągle nowy. W ten sposób wolność stanowi podstawę i bodziec dla kulturowej kreatywności we wszystkich dziedzinach techniki i wszystkich obszarach sztuki ${ }^{53}$.

Jak więc można zauważyć, antropologia teologiczna oparta o świadectwo Biblii stanowi wielką i złożoną bazę treści dla antropologii filozoficznej. Po przedstawieniu ogólnego szkicu orientacyjnego, kolejnym krokiem winno być analityczne przedstawienie przesłania egzegetycznego poszczególnych jej aspektów.

Poznań

KS. STANISŁAW ORMANTY TChr.

\section{Summary}

\section{Man as a Personal Being in the Light of Biblical Anthropology}

This article presents a general outline of biblical anthropology that constitutes the contents foundation of philosophical anthropology. Within the scope of the biblical view of man two basic dimensions of man play the decisive role: the personal and the social dimension. The personal being and the social being remain in close relationship with each other.

Being a person on the human level is characterized by direction towards community and development within community. Furthermore, a specifically human community takes shape through respect for and support of human personality. A human person is a relation; only through the relation man becomes a person in its entireness. In other words, a human being exists within communication, realizes himself by means of communication.

${ }^{50}$ Zob. R. ŁUKASZYK, Osobowy charakter wiary religijnej, [w:] W kierunku człowieka, red. B. Bejze, Warszawa 1971, s. 202; M. FiLipiaK, Biblia o człowieku, dz. cyt., s. 103.

${ }^{51}$ Zob. M. Gogacz, Wokót problemu osoby, dz. cyt., s. 41-42.

${ }^{52}$ Zob. M. JęDraszeski, Antropologia filozoficzna, t. 3, Poznań 1991, s. 24-26.

${ }_{53}$ Zob. J. SIEG, Kultura, praca i technika, [w:] Człowiek-istnienie-działanie, red. R. DAROwski, Kraków 1974, s. 139-192. 
The notion of person can be described by distinguishing and emphasizing its various facets: a person is an individual founded in the spiritual nature, possessing a quality of irreplaceable or non-interchangeable autonomy. A person is shaped by spirit and constitutes an unrepeatable and self-governed unity and wholeness.

This article presents man as wholeness to which belong three basic human manifestations: that of the body, the soul and the spirit, as it is presented in the Judaistic biblical exegesis of Creation (Gen. 2: 7). Within the spiritual aspect of man focus was placed on the notions of reason and freedom as well as language and culture. 